ARTICLE OPEN

\title{
The polar night shift: seasonal dynamics and drivers of Arctic Ocean microbiomes revealed by autonomous sampling
}

\author{
Matthias Wietz $\mathbb{D}^{1,2^{凶}}$, Christina Bienhold (iD ${ }^{1,2}$, Katja Metfies ${ }^{3}$, Sinhué Torres-Valdés (iD) ${ }^{4}$, Wilken-Jon von Appen ${ }^{5}$, lan Salter ${ }^{1,6}$ and \\ Antje Boetius (D) $1,2,7 \mathbb{m}^{\prime}$
}

(c) The Author(s) 2021

The Arctic Ocean features extreme seasonal differences in daylight, temperature, ice cover, and mixed layer depth. However, the diversity and ecology of microbes across these contrasting environmental conditions remain enigmatic. Here, using autonomous samplers and sensors deployed at two mooring sites, we portray an annual cycle of microbial diversity, nutrient concentrations and physical oceanography in the major hydrographic regimes of the Fram Strait. The ice-free West Spitsbergen Current displayed a marked separation into a productive summer (dominated by diatoms and carbohydrate-degrading bacteria) and regenerative winter state (dominated by heterotrophic Syndiniales, radiolarians, chemoautotrophic bacteria, and archaea). The autumn postbloom with maximal nutrient depletion featured Coscinodiscophyceae, Rhodobacteraceae (e.g. Amylibacter) and the SAR116 clade. Winter replenishment of nitrate, silicate and phosphate, linked to vertical mixing and a unique microbiome that included Magnetospiraceae and Dadabacteriales, fueled the following phytoplankton bloom. The spring-summer succession of Phaeocystis, Grammonema and Thalassiosira coincided with ephemeral peaks of Aurantivirga, Formosa, Polaribacter and NS lineages, indicating metabolic relationships. In the East Greenland Current, deeper sampling depth, ice cover and polar water masses concurred with weaker seasonality and a stronger heterotrophic signature. The ice-related winter microbiome comprised Bacillaria, Naviculales, Polarella, Chrysophyceae and Flavobacterium ASVs. Low ice cover and advection of Atlantic Water coincided with diminished abundances of chemoautotrophic bacteria while others such as Phaeocystis increased, suggesting that Atlantification alters microbiome structure and eventually the biological carbon pump. These insights promote the understanding of microbial seasonality and polar night ecology in the Arctic Ocean, a region severely affected by climate change.

ISME Communications; https://doi.org/10.1038/s43705-021-00074-4

\section{INTRODUCTION}

Microbes are fundamental for the marine biosphere and have been recognized as key components of global change biology [1]. Understanding the causes, complexity, and consequences of microbial community dynamics significantly benefits from continuous observations in the physicochemical context. Ocean time series are beginning to discern the temporal variability and environmental drivers of marine microbiomes from diurnal to decadal scales, but focusing on temperate and tropical waters to date [2-6]. In contrast, continuous records from the polar oceans are rare. Pioneering studies have identified variable numbers, activities, and communities of polar microbes over time and space [7-13] indicating considerable seasonal contrasts [14], yet with limited temporal or spatial resolution.

Due to the extreme winter conditions and remoteness, continuous observations covering the polar night have been seldom accomplished through shipboard expeditions, or performed in coastal areas $[15,16]$. New autonomous technologies are a key advance for year-round studies in polar waters, recently providing the first annual records in the Arctic and Antarctic Oceans $[17,18]$. Such approaches can identify transition phases in the seasonal interplay between ocean physics and the ecosystem, for instance the onset of the spring bloom or the end of net growth. In this regard, the polar night is of key interest, when physical mixing $[19,20]$ and microbial activities $[21,22]$ replenish nutrients to fuel the subsequent phytoplankton bloom. Arctic phototrophic taxa are thought to overwinter in dormancy [23], responding rapidly when light returns [15, 24], but recent evidence suggests that primary production might already start from late winter [18]. However, microbial dynamics in the open Arctic Ocean during the polar night, especially in presence of sea ice, remain largely unknown.

Here, using an array of autonomous samplers and sensors, we portray microbial and oceanographic seasonality in the two major hydrographic regimes of the Fram Strait. This main deep-water gateway to the central Arctic Ocean harbors the northward, relatively warm and ice-free West Spitsbergen Current (WSC) and the southward, ice-covered and cold East Greenland Current

\footnotetext{
${ }^{1}$ Deep-Sea Ecology and Technology, Alfred Wegener Institute Helmholtz Centre for Polar and Marine Research, Bremerhaven, Germany. ${ }^{2}$ Max Planck Institute for Marine Microbiology, Bremen, Germany. ${ }^{3}$ Polar Biological Oceanography, Alfred Wegener Institute Helmholtz Centre for Polar and Marine Research, Bremerhaven, Germany. ${ }^{4}$ Marine BioGeoScience, Alfred Wegener Institute Helmholtz Centre for Polar and Marine Research, Bremerhaven, Germany. ${ }^{5}$ Physical Oceanography of the Polar Seas, Alfred Wegener Institute Helmholtz Centre for Polar and Marine Research, Bremerhaven, Germany. ${ }^{6}$ Faroe Marine Research Institute, Tórshavn, Faroe Islands. ${ }^{7}$ MARUM Center for Marine Environmental Sciences, University of Bremen, Bremen, Germany. ${ }^{凶}$ email: matthias.wietz@awi.de; Antje.Boetius@awi.de
}

Received: 8 June 2021 Revised: 3 November 2021 Accepted: 15 November 2021

Published online: 11 December 2021 

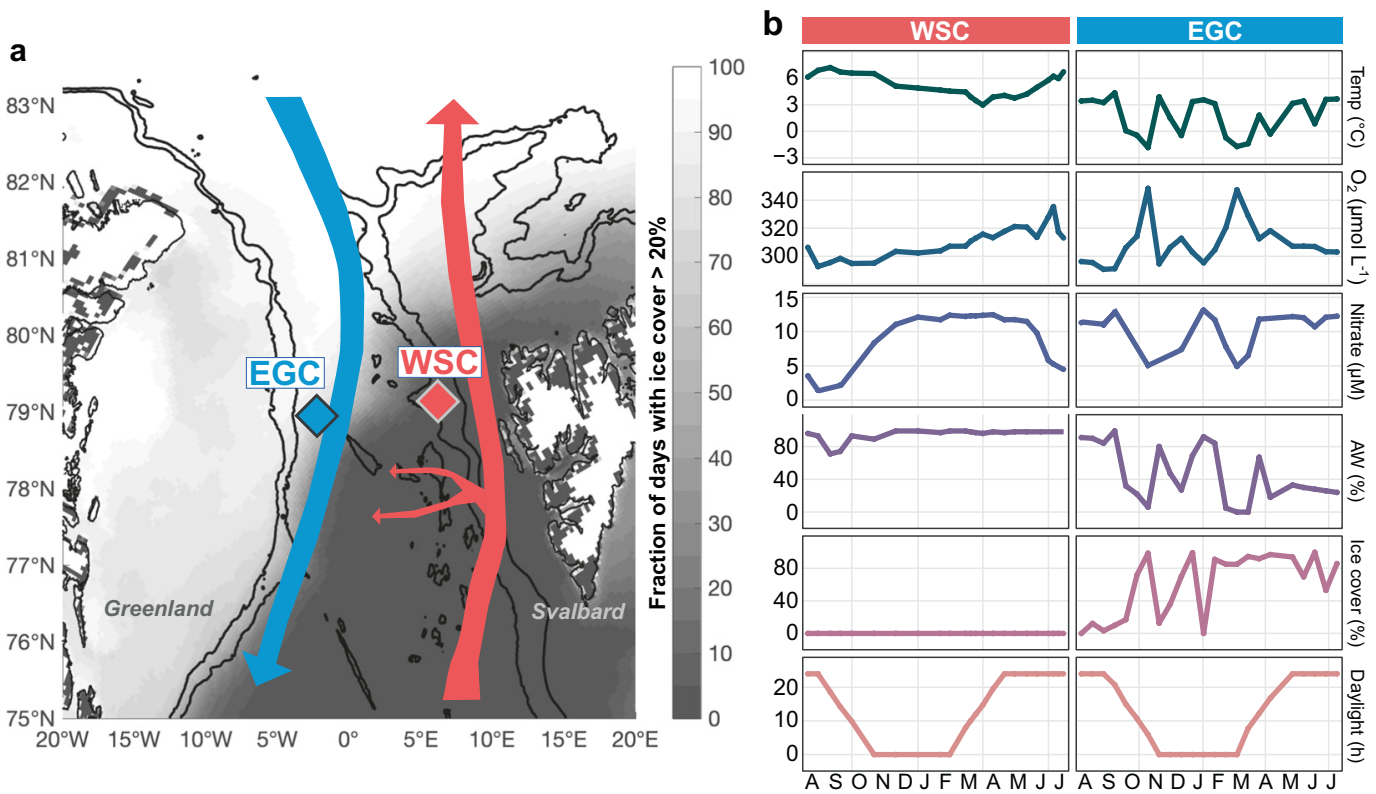

Fig. 1 Study area and oceanographic conditions. a Location of moored Remote Access Samplers in the East Greenland Current (EGC) and the West Spitsbergen Current (WSC) of Fram Strait, indicated in blue and red respectively. The small red arrows illustrate recirculation of Atlantic Water in central Fram Strait. The grayscale gradient indicates the fraction of days with average sea ice cover of $>20 \%$. b Water temperature $\left({ }^{\circ} \mathrm{C}\right)$, concentrations of oxygen $\left(\mu \mathrm{mol} \mathrm{L^{-1 } )}\right.$ and nitrate $(\mu \mathrm{M})$, the proportion of Atlantic Water $(\%)$, sea ice cover $(\%)$, and daylight hours.

(EGC), with some recirculation in central Fram Strait across the marginal ice zone (Fig. 1a). Our study is embedded in the longterm HAUSGARTEN observatory studying primary production, benthopelagic coupling, and deep-sea ecology since the 1990s $[25,26]$. The recent deployment of autonomous devices within the FRAM infrastructure program affords the unique opportunity for continuous year-round records. These considerably expand summertime observations of microbial diversity and activity in the WSC and EGC [27-32], shaped by a combination of sea ice cover, nitrate availability, and mixed layer depth [33, 34]. Annual records also help to understand the biological responses to the northward expansion of subarctic habitats, termed Atlantification, which propagates through the entire food web [35].

Here we investigated how polar day and night shape seasonality, expecting considerable differences between summer and winter microbiomes in both regions. We hypothesized that phototrophy- and heterotrophy-dominated periods in the WSC harbor markedly dissimilar microbial communities, whereas sea ice cover and polar water masses in the EGC sustain winter-type communities year-round. Our study illuminates fundamental principles of seasonality in Arctic microbial diversity, the ecological importance of the polar night, and potential effects of Atlantification. This evidence helps understanding natural variability and human impact in a region under severe threat by climate change $[36,37]$, with important implications for the present and future Arctic Ocean.

\section{MATERIALS AND METHODS \\ Sampling approach}

Within the framework of the FRAM marine observatory (https://www.awi. de/en/expedition/observatories/ocean-fram.html), Remote Access Samplers (RAS; McLane, East Falmouth, MA) were deployed in July 2016 on seafloor moorings F4-S-1 in the core WSC (79.0118 N $6.9648 \mathrm{E})$ and EGC-3 in the marginal ice zone $(78.831 \mathrm{~N}-2.7938 \mathrm{E})$, constituting a fixed-point Eulerian approach (Fig. 1a). RAS deployment depth was $30 \mathrm{~m}$ (WSC) and 80 $\mathrm{m}$ (EGC; to avoid ice collisions). However, vertical movements in the water column resulted in variable actual sampling depths, with a mean of $40 \mathrm{~m}$ and $90 \mathrm{~m}$ in the WSC and EGC respectively (Supplementary Table 1). RAS frames were equipped with 48 sterile sampling bags, each containing $700 \mu \mathrm{L}$ of saturated $(7.5 \% \mathrm{w} / \mathrm{v})$ mercuric chloride solution. At each programmed sampling event, two water samples of $500 \mathrm{~mL}$ were autonomously pumped an hour apart into individual sampling bags and fixed by mixing with mercuric chloride $(0.01 \%$ final concentration). Upon recovery in August 2017, samples were immediately filtered through 0.22 $\mu \mathrm{m}$ Sterivex cartridges (Millipore, Burlington, MA) and frozen at $-20^{\circ} \mathrm{C}$ until DNA extraction.

\section{DNA extraction and amplicon sequencing}

DNA was extracted using the PowerWater kit (QIAGEN, Germany) according to the manufacturer's instructions, and quantified using Quantus (Promega, Madison, WI). 16S and 18S rRNA gene fragments were amplified using primers 515F-926R [38] and 528iF-964iR [29] respectively. Libraries were prepared according to the $16 \mathrm{~S}$ Metagenomic Sequencing Library Preparation protocol (Illumina, San Diego, CA). rRNA gene fragments were sequenced using MiSeq technology in $2 \times 300$ bp paired-end runs (Supplementary Methods).

\section{Sequence analysis}

After primer removal using cutadapt [39], 16S and 18S rRNA reads were processed into amplicon sequence variants (ASVs) using DADA2 v1.14.1 [40] and classified using taxonomy databases Silva v138 [41] and $\mathrm{PR}^{2}$ v4.12 [42] respectively (Supplementary Methods). After singleton removal, we obtained on average $62,00016 \mathrm{~S}$ rRNA and 99,000 18S rRNA reads per sample (Supplementary Table 2) sufficiently covering community composition (Supplementary Fig. 1). Sequences have been deposited in the European Nucleotide Archive under accession numbers PRJEB43890 (16S rRNA) and PRJEB43504 (18S rRNA) using the data brokerage service of the German Federation for Biological Data (GFBio) in compliance with MIxS standards.

\section{Mooring and satellite data}

Temperature, depth, salinity, oxygen concentration, and oxygen saturation were derived from Seabird SBE37-ODO CTD sensors attached to the RAS, confirming consistent properties of the two water samples per date. Sensor measurements were averaged over $4 \mathrm{~h}$ around each sampling event, allowing to determine the relative proportions of Atlantic Water (AW) and Polar Water (PW) (Supplementary Methods). Relative proportions of $>80 \%$ were considered as pure Atlantic or Polar Water respectively; and $20-80 \%$ as mixture of both. Physical sensors were manufacturer-calibrated 


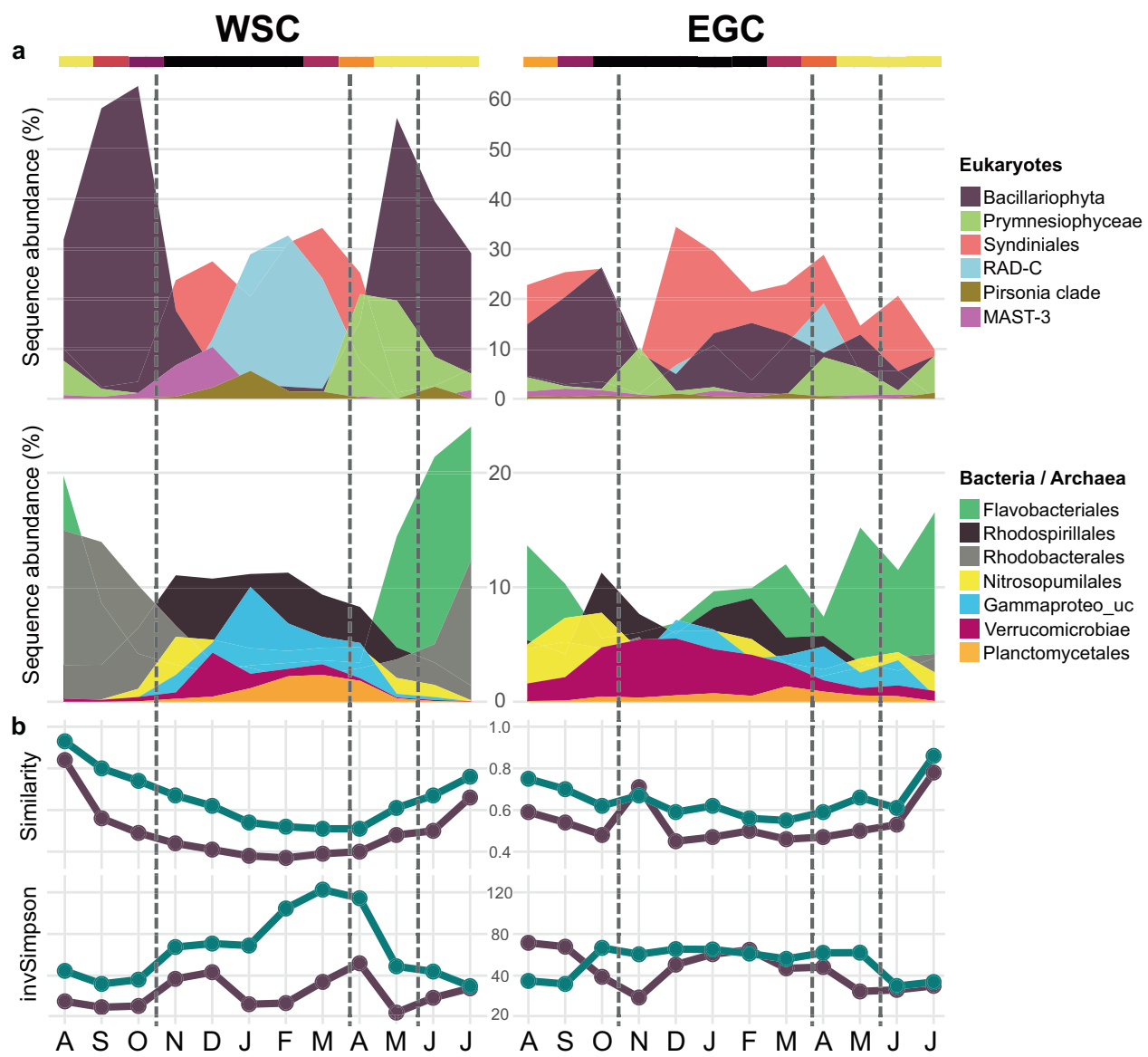

Fig. 2 Year-round microbial community structure and turnover. a Relative sequence abundances (\%) of eukaryotic, bacterial and archaeal taxa over the annual cycle. b, upper panel: Microbial community turnover (taxonomic similarities expressed as 1 minus Jenson-Shannon distance) compared to the first sampling event in relation to daylight hours (top color gradient). b, lower panel: Microbial alpha-diversity (inverse Simpson index). Eukaryotes: purple; bacteria and archaea: green. Lines indicate the seasonal boundaries defined by multivariate evaluation of physicochemical and microbial dynamics (Fig. 3).

and processed in accordance with https://epic.awi.de/id/eprint/43137. For

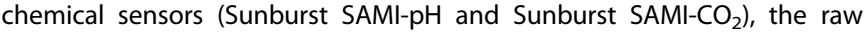
readouts are reported. Mooring data are available under https://doi. pangaea.de/10.1594/PANGAEA.904565. Sea ice and surface chlorophyll concentrations, derived from the AMSR-2 and Sentinel 3A OLCl satellites, were downloaded from the University of Bremen and the European Space Agency respectively, considering grid points within a radius of $15 \mathrm{~km}$ around the moorings.

\section{Nutrient quantification}

Nitrate, nitrite, phosphate, and silicate were quantified using a QuAAtro Seal Analytical segmented continuous-flow autoanalyser following standard colorimetric techniques. Accuracy was evaluated using KANSO LTD Japan Certified Reference Materials, with corrections applied as required. Following quality controls, results deemed questionable or of bad quality (quality flags 4 or 8 respectively) were excluded from further analyses (labeled NA in Supplementary Table 1). Nutrient data are available under https://doi.pangaea.de/10.1594/PANGAEA.936749.

\section{Statistical evaluation}

Data analysis was done in R v4.1.1 implemented in RStudio (https://rstudio. com). In short, alpha-diversity and rarefaction curves were computed on raw ASV counts using $R$ package iNEXT [43], excluding metazoan, chloroplast, and mitochondrial sequences. Subsequently, we only considered reads with $\geq 3$ counts in $\geq 2$ samples. Also, two samples from $>200$ $\mathrm{m}$ depth, when the RAS was pushed down by currents, were discarded to omit deep-water signatures. NMDS was performed using Bray-Curtis dissimilarities on Hellinger-transformed relative abundances. Seasons were defined based on multivariate patterning of oceanographic parameters and microbial community composition (Figs. 2, 3). Statistical differences were computed by PERMANOVA or Kruskal-Wallis plus Bonferronicorrected Dunn's post-hoc test as appropriate. Pairwise associations were assessed by Spearman correlations. Major R packages used were tidyverse, phyloseq, ampvis2, and PNWColors [44-47]. Code for reproducing workflow and figures is available at https://github.com/matthiaswietz/RAS-1617.

\section{RESULTS AND DISCUSSION}

The present study elucidates microbial and oceanographic seasonality in the WSC and the EGC of Fram Strait using automated, year-round high-frequency sampling (Fig. 1a). For this purpose, seawater was autonomously collected and preserved in situ using moored Remote Access Samplers (RAS) in weekly to monthly intervals (Supplementary Table 1). In addition, sensors continuously measured depth, temperature, salinity, and oxygen, informing about oceanographic conditions including the proportions of Atlantic Water (AW) and Polar Water (PW). After recovery, water samples were subjected to amplicon sequencing of microbial communities and quantification of inorganic nutrients. Bacterial, archaeal, and eukaryotic amplicon sequence variants (ASVs) were then evaluated in the oceanographic context, including satellite-derived ice and chlorophyll concentrations (Supplementary Table 1).

\section{Major annual dynamics and drivers}

Environmental conditions and microbial communities substantially differed over the year, but also between the two sampling sites (Fig. 1b, Supplementary Figs. 2, 3). At the WSC mooring, 


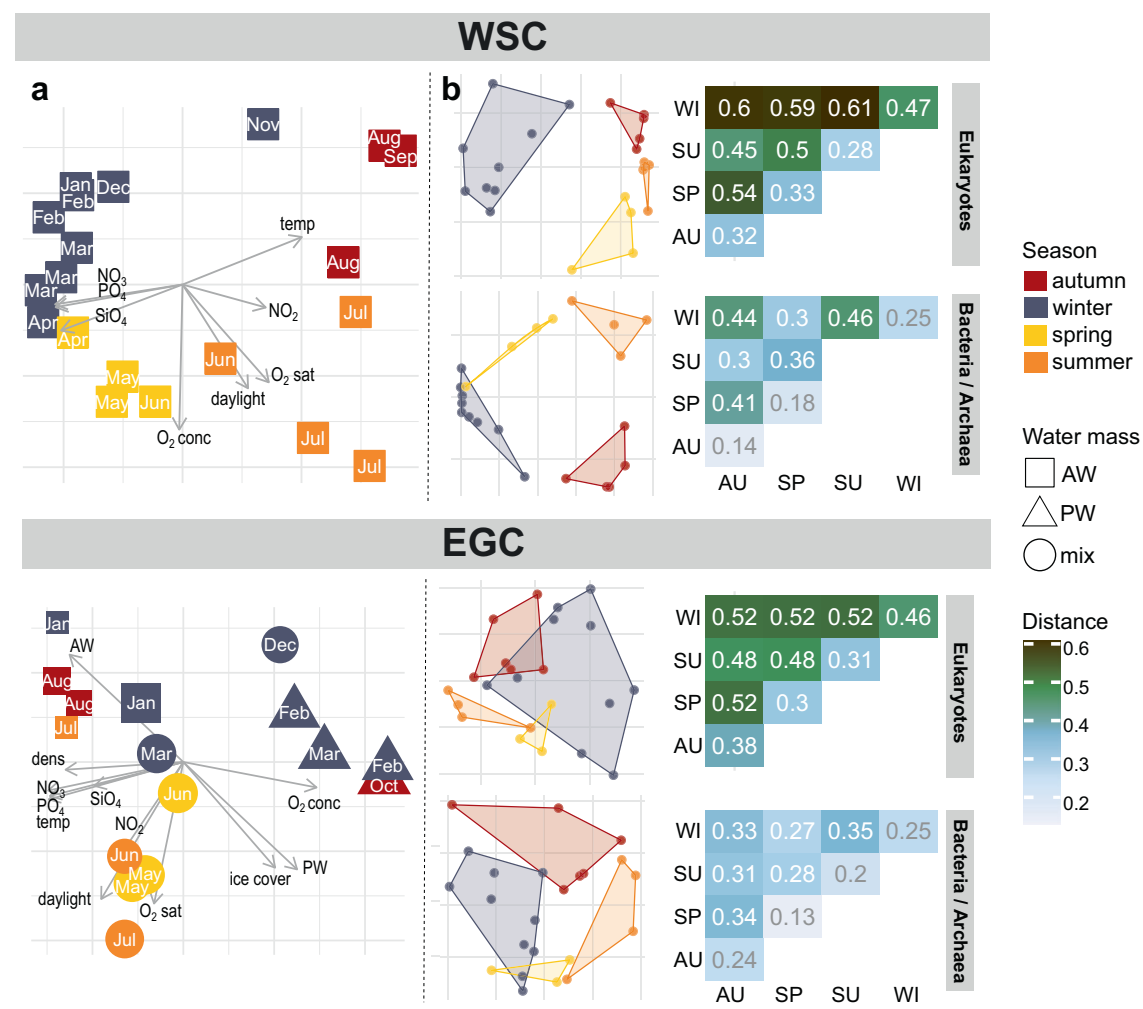

Fig. 3 Microbial and environmental seasonality. a Principal Component Analysis of environmental conditions. Components 1 and 2 explained $58 / 26 \%$ (WSC) and 60/14\% (EGC) respectively, and hence the majority of physicochemical variability. For EGC, label size indicates percent ice cover. Only sampling events with complete environmental data were considered. b Non-metric multidimensional scaling of Hellinger-transformed relative ASV abundances (stress values $0.07,0.03,0.13,0.1$ from top to bottom) and corresponding Jensen-Shannon distances between and within seasons (larger numbers designate more dissimilar communities).

ice-free AW prevailed throughout the year, with water temperatures between 3.0 and $7.2^{\circ} \mathrm{C}$ at sampling depth (Supplementary Table 1). Stratification in summer and mixing of the water column in winter $[48,49]$ corresponded to a mixed layer depth between 0 (July/August) and $270 \mathrm{~m}$ (February). At the EGC mooring, deployed at the edge of the marginal ice zone, water temperature varied between -1.8 and $4.4^{\circ} \mathrm{C}$. Intermittent advection of AW resulted in dynamic changes between polar (cold/ice-rich) and Atlantic (warmer/low-ice) conditions (Fig. 1b). PW-dominated periods showed a specific physicochemical and microbial signature, whereas AW advection resulted in greater similarities to the WSC (Supplementary Figs. 2, 3). This connection was strongest between AW proportions and bacterial composition (Spearman's $r h o=0.4 ; p=0.00008$ ). Hence, differences between the WSC and EGC correspond to different hydrography, ice cover as well as sampling depth. Earlier studies investigated the background of these vertical and horizontal contrasts in hydrography [33] and microbial composition [29].

This study focuses on the seasonal shifts in microbial communities. In both the WSC and EGC, communities markedly changed in composition and diversity over the annual cycle (Fig. 2a), illustrating dynamic microbiome structures year-round. Taxonomic dissimilarities to the first sampling event peaked around the March equinox before increasing again towards peak polar day (Fig. 2b), indicating light-driven temporal recurrence [50]. Notably, bacterial but not eukaryotic alpha-diversity correlated with daylight hours in both regions (Spearman's $r h o=0.6, p<0.006$ ).

\section{Microbial and environmental seasonality}

We contextualized major patterns in microbial and physicochemical variability (Figs. 2-4) to delineate the four seasons: spring (midApril to mid-June), summer (mid-June to late-July), autumn (August to October), and winter (November to mid-April). Comparing all sampling events in the WSC and EGC, community structures largely clustered by season, with up to $\sim 60 \%$ compositional dissimilarity to the other seasons respectively. Nonetheless, region-specific subclusters underlined the influence of hydrographic differences on microbiome composition (Supplementary Fig. 4). Seasonal contrasts in physicochemistry (Fig. 3a, Supplementary Table 3) and community composition (Fig. 3b, Fig. 4, Supplementary Fig. 5a) were most pronounced in the WSC, corroborated by season-specific correlations between microbial taxa and environmental parameters (Fig. 5). Weaker seasonality in the EGC corresponded to the combined influence of deeper sampling depth, sea ice cover, and the proportions of PW (Figs. 3b, 5). In line with recent metagenomic evidence, these patterns indicate a considerable degree of temporal specialization among Fram Strait microbiomes [51, 52], although the abundant SAR11 and SAR86 clades (constituting on average $25 \pm 6 \%$ and $8 \pm 3 \%$ of sequences, respectively) varied little over the year (Supplementary Fig. 5a).

In the WSC, daylight and temperature were significant drivers of eukaryotic variability (PERMANOVA, $p<0.001$ ), whereas bacterial composition varied mostly with temperature (PERMANOVA, $p<$ $0.001)$, comparable to the global TARA microbiome study [53]. Bacterial alpha-diversity peaked at the end of polar night (Fig. 2b) when water temperatures were lowest (Fig. 1b), underlining the day-night shift as key transition event. ASVs associated with Bacillariophyta (i.e. diatoms) and Flavobacteriales predominated from spring to autumn (Fig. 2a), presumably corresponding to metabolic interrelations through algal carbohydrates [54]. In contrast, heterotrophic eukaryotes (foremost Syndiniales and RAD-C radiolarians), archaea (Nitrosopumilales) and specific bacterial taxa (e.g., Rhodospirillales) prevailed in winter, with additional short-lived peaks of the diatom parasites Pirsonia and 


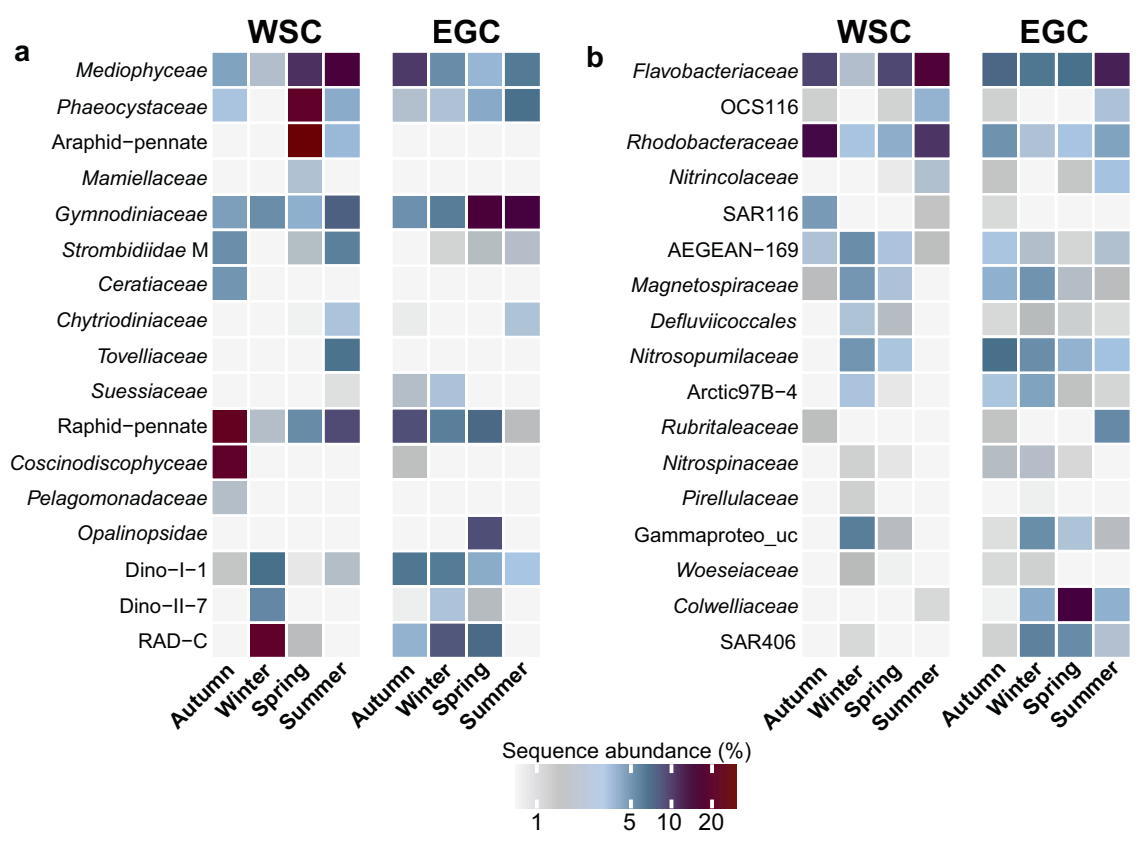

Fig. 4 Microbes as indicators for seasons. Relative sequence abundances of major microbial families by season and region (see Supplementary Fig. 5a for details).

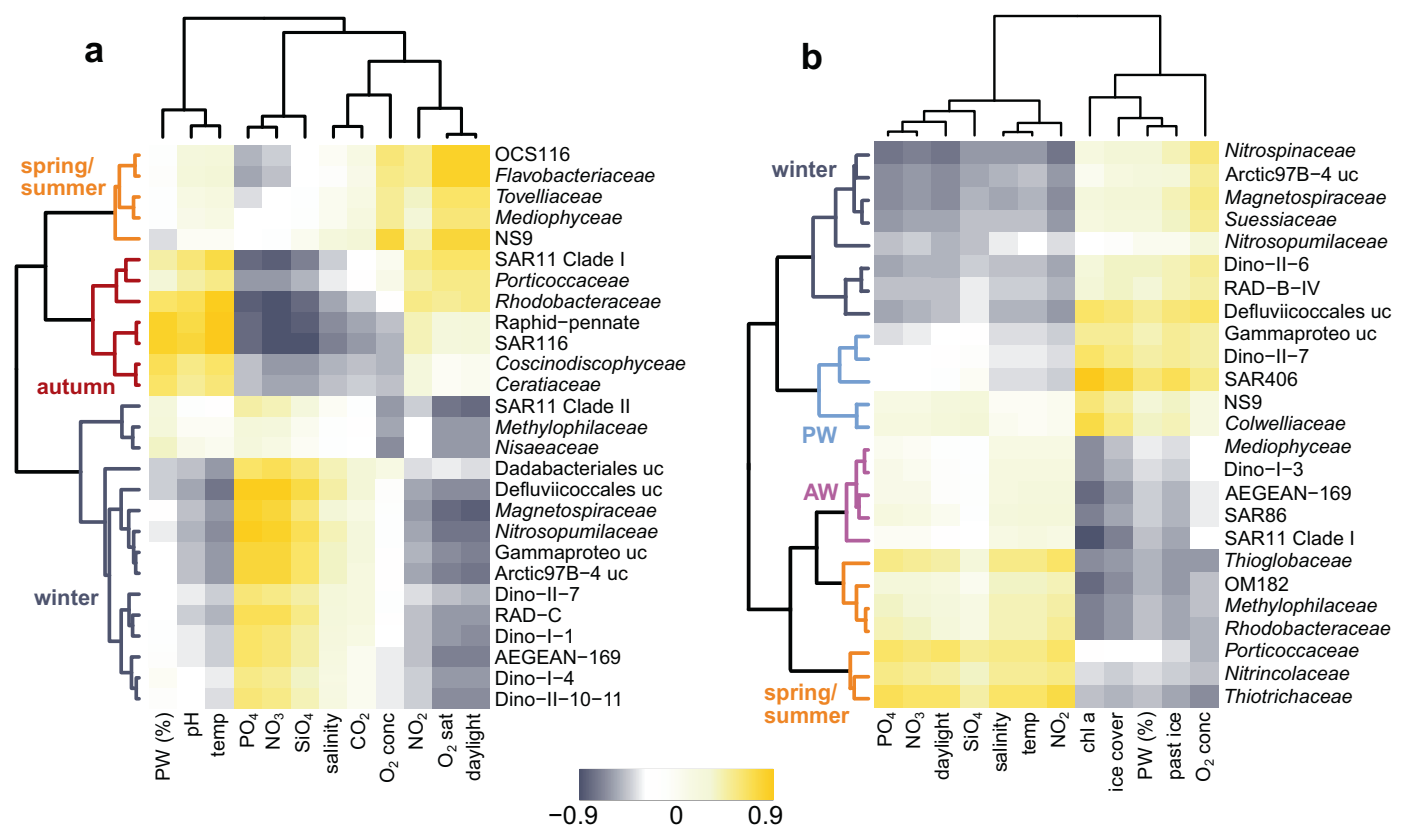

Fig. 5 Environmental drivers of community structure. Partial Least Square regression between environmental parameters and the abundance of microbial families, identifying seasonal groupings in the WSC (a) compared to both seasonal and polar/Atlantic-influenced groupings in the EGC (b). Only correlation coefficients $>0.5$ were considered. Temp: water temperature; $\mathrm{O}_{2}$ conc: oxygen concentration; $\mathrm{O}_{2}$ sat: oxygen saturation; PW: proportion of Polar Water; ice cover: percent ice cover on a given sampling event; past ice: percent ice cover integrated over the time between sampling events; $\mathrm{CO}$ : partial $\mathrm{CO}_{2}$ pressure.

MAST-3 (Fig. 2a). We consider these taxa as "microbial recyclers" persisting on detrital, inorganic or semi-refractory substrates. For instance, as detailed below, Nitrosopumilales are involved in ammonia oxidation and hence nitrate replenishment. The separation into photoautotrophy- and heterotrophy-driven periods of production and recycling was reflected in nutrient concentrations, with depletion in summer and replenishment during winter (Fig. 1b, Supplementary Table 1).

In the EGC, changes between polar and Atlantic conditions caused more variable community composition, turnover and diversity. For instance, environmental conditions during AW advection in January resembled those in August (Figs. 1b, 3a). Daylight, temperature, hydrography and ice cover all contributed to microbial community structuring (PERMANOVA, $p<0.05$ ). This explained why some taxa correlate with seasonally changing environmental parameters, and some with polar or Atlantic conditions (Fig. 5). Constant proportions of photoautotrophic and heterotrophic eukaryotes year-round, with $\sim 50 \%$ lower diatom abundances than in the WSC (Fig. 2a, Supplementary Fig. 5b), illustrated a more heterotrophic food web largely 

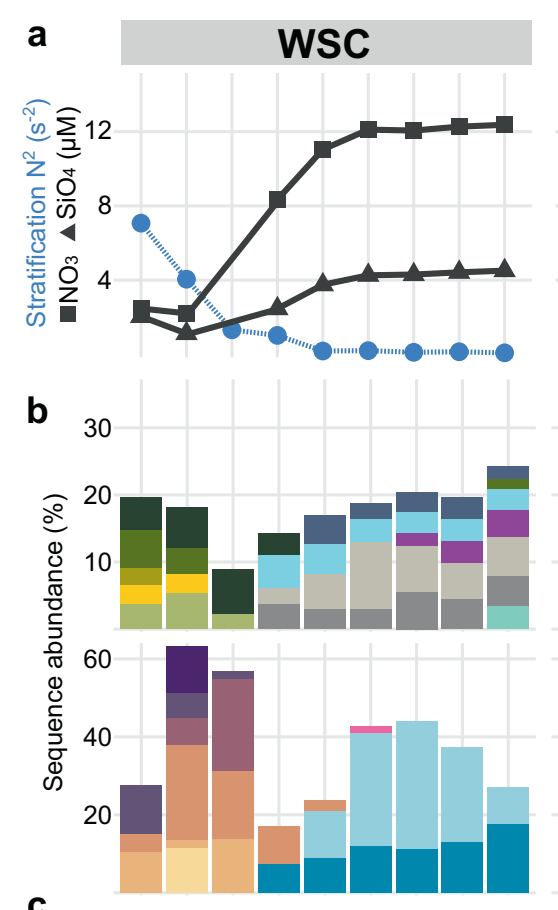

C

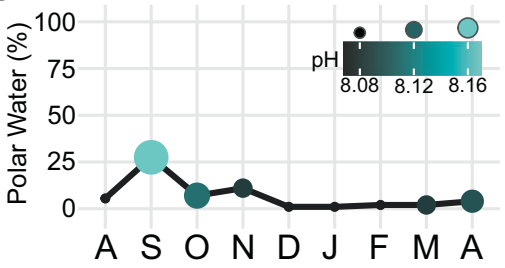

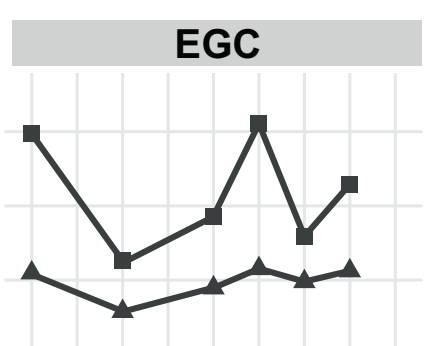
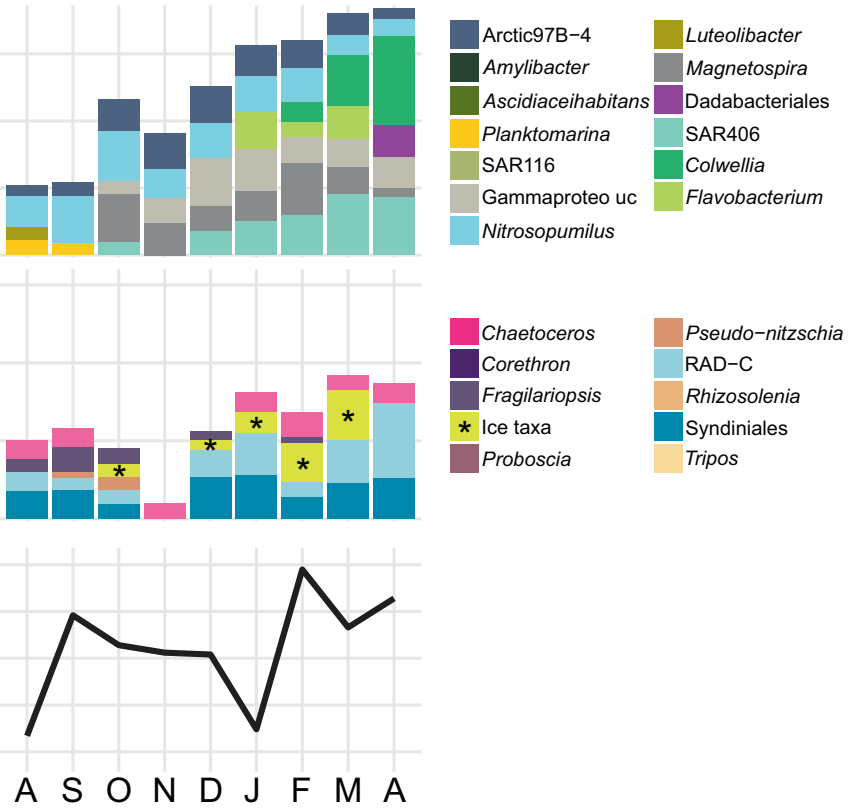

Fig. 6 Autumn and winter dynamics. a Concentrations of nitrate (squares) and silicate (triangles) in relation to stratification (blue; only available for the WSC). b Microbial genera with increased proportions in autumn or winter. "Winter-ice" eukaryotes are combined (marked by asterisks; see Supplementary Fig. 7a for abundances of each genus). c pH values (only available for the WSC) and proportions of Polar Water.

determined by sampling depth [55]. Sensor data available from autumn 2017 onwards show that $<1 \%$ of photosynthetically active radiation reaches $80 \mathrm{~m}$, impeding primary production. Furthermore, stratification in the upper $\sim 50 \mathrm{~m}$ is strong $[33,34]$. Detected phytoplankton sequences thus largely correspond to sinking cells from surface blooms and ice $[56,57]$. In this context, high ice cover between May and July presumably repressed light availability and hence surface primary production, while stimulating the downward flux of ice-derived microbes. This combination of factors contributed to the weaker seasonality and temporal lag in the detection of certain phytoplankton taxa. For instance, Phaeocystaceae and Mediophyceae primarily occurred in summer/autumn (EGC) compared to spring/summer (WSC) respectively (Fig. 4). Nonetheless, our results indicate some overarching seasonal principles, especially during AW recirculation to the EGC. In the following, we present a detailed synopsis of seasonal patterns and specific events in chronological order from autumn 2016 to summer 2017.

\section{Autumn}

Autumn in the WSC was characterized by nitrate, silicate and phosphate depletion and a specific community of Coscinodiscophyceae, Ceratiaceae, SAR116 and Rhodobacteraceae (Figs. 3, 4-6, Supplementary Table 3). These patterns illustrate a post-bloom state, with growing decay of summer phytoplankton [58] and concurrent increase in mixotrophic dinoflagellates [59]. The prevalence of Corethron, Rhizosolenia and Proboscia sequences (Fig. 6b, Supplementary Fig. 5b) matched microscopic cell counts [60], corroborating our amplicon-based results. Similar autumn patterns in the Southern Ocean indicate bi-polar seasonal preferences of Coscinodiscophyceae, likely facilitated by their ability to overcome silicate limitation [61], use ammonium instead of nitrate [17], and resist grazing [62]. Appearance of chytrid fungi and Labyrinthulaceae at maximal nutrient depletion in October (Supplementary Fig. 6) indicates saprophytic activity on decaying algae [63, 64]. Up to 13-fold higher abundances of Cand. Puniceispirillum, other SAR116 members as well as Ascidiaceihabitans, Amylibacter and Planktomarina (Fig. 6b) were probably fueled by DMSP and senescence compounds from decaying phytoplankton $[65,66]$. Detection of Luteolibacter from the Rubritaleaceae family (Fig. 5b) mirrored autumn in coastal Svalbard [67] and suggested ongoing particle formation, typical processes in ageing phytoplankton [68]. Overall, the average mixed layer depth of $17 \mathrm{~m}$ (Supplementary Table 3) suggests that microbial signals partially correspond to cells sinking from the shallow productive layer.

Fragilariopsis co-occurred in the WSC and the EGC during early autumn (Fig. 5b). We hypothesize that this typically ice-associated taxon was transported to the WSC by advection, considering the higher proportion of PW during this time (Fig. 6c). This event also covaried with higher $\mathrm{pH}$, with potential metabolic effects on prevalent taxa such as Pseudo-nitzschia [69]. Otherwise, the EGC displayed quite different dynamics. Peaking diatom abundances characterized autumn as major photosynthetic period (Fig. 4, Supplementary Fig. 5b). We attribute this delay to the low ice cover (Fig. 1b, Supplementary Table 3) enhancing light penetration and stratification [70]. This combination presumably allowed an autumn surface bloom, becoming subsequently detectable at $80 \mathrm{~m}$ once phytoplankton cells sank. 


\section{Winter}

The WSC and EGC shared elevated abundances of Magnetospiraceae, Nitrospinaceae, the Arctic97B-4 clade and unclassified Gammaproteobacteria (Figs. 4, 5b), although their wintersummer contrasts were stronger in the WSC (average KruskalWallis significance $p \leq 0.003$ vs. 0.02 in the EGC). Furthermore, Dadabacteriales appeared from February (WSC) or late March (EGC) (Fig. 6) and might contribute to the recycling of organic matter [71]. Fundamental regional differences were the complete switch to heterotrophy in the WSC, compared to ice-related microbial signatures including persistent diatom signals in the EGC.

Heterotrophic winter communities of the WSC. The increase of Syndiniales, parasitic recyclers of phytoplankton biomass [72], in November marked the onset of winter (Supplementary Fig. 6). Bacterial diversification and nutrient replenishment (Figs. 2, 6) followed the breakdown of summer stratification, with maximal mixing of the water column in January (Fig. 6a). At this time, heterotrophic eukaryotes constituted $\sim 70 \%$ of sequences and nutrient standing stocks were restored (Figs. 2a, 6a). The parallel decline of phototrophs to a combined relative abundance of $<5 \%$ (Supplementary Fig. 5b) indicated complete mixing as one central turning point of the annual cycle [73, 74]. Notably, this also illustrates that only a small "seed bank" overwintered to initiate the following spring bloom. The upward transport of microbes during mixing likely enriched the community's metabolic potential [75]. For instance, appearance of deep-water RAD radiolarians [76] possibly contributed to the recycling of phytoplankton biomass. Stratification potentially also influenced the temporal succession of different Syndiniales lineages over winter (Supplementary Fig. 6).

Winter bacteria and archaea likely contributed to nutrient replenishment. The co-occurrence of Nitrosopumilaceae and Nitrospinaceae (Figs. 4, 6b), the major drivers of marine nitrification, suggests an interactive niche with initial oxidation of ammonia or urea by Nitrosopumilaceae and subsequent nitrite oxidation by Nitrospinaceae [77]. In addition, the Magnetospiraceae family (Rhodospirillales) might recycle nitrogen by fixation and contribute to a yet underestimated nitrogen source [78, 79]. Furthermore, metaproteomic data indicate that Magnetospiraceae perform $\mathrm{CO}_{2}$ fixation and thiosulfate oxidation [13]. Overall, genomic and metabolic evidence suggests consistent roles of Nitrosopumilaceae, Nitrospinaceae, and Magnetospiraceae during winter in both Arctic and Antarctic Oceans [80, 81]. Further potential recyclers are the Pirellulaceae and Woeseiaceae through ammonia oxidation and denitrification respectively $[82,83]$. The winter niche of Defluviicoccales was potentially fueled by stored glycogen or unsaturated aliphatics $[84,85]$. Overall, the prevalence of diverse heterotrophic and chemoautotrophic taxa illustrates the polar night as important recycling phase before the spring bloom. Furthermore, the winter microbiome is not static, but responsive to certain stimuli such as mixing.

An ice-related microbial loop in the EGC. Unique to the EGC was the persistence of raphid-pennate diatoms and flavobacteria throughout winter (Fig. 4), contrasting their light-correlated seasonality in the WSC. We attribute these signals to ice melt and release of cells into the water, following intermittent water temperatures of $>2{ }^{\circ} \mathrm{C}$ during AW advection in January (Fig. 1b). The diatoms Bacillaria and Naviculales, together with Polarella and Chrysophyceae flagellates, constituted up to $15 \%$ of sequences between February and March (Fig. 6b, Supplementary Fig. 7a). All of these taxa occur in sea ice and the underlying water $[56,86]$, possibly constituting an ice-related microbial loop. Ice algae produce copious amounts of storage polysaccharides and extracellular polymeric substances, fueling bacterial growth in the underlying water $[70,87]$. Bacillaria exudates are a valuable nutrient source for bacteria [88], as is chrysolaminarin from diatoms and Chrysophyceae [89]. Concurrently, Chrysophyceae potentially also influenced organic matter cycling by preying on bacteria [90]. A Flavobacterium ASV constituted $\sim 10 \%$ between January and March (Fig. 6b, Supplementary Fig. 7a), sharing $>99 \%$ sequence similarity with Flavobacterium frigidarium, a psychrophilic genus with laminarinolytic abilities [91]. Detection of related sequences on ice-algal aggregates [92] supports a presumed niche of this ASV through utilization of ice-algal carbohydrates. Overall, such ice-fueled processes might explain signatures and activities of specific microbial taxa in the warming Arctic [93, 94].

An EGC-specific winter bacterium was the SAR406 clade, peaking at $9 \%$ sequence abundance in March and remaining detectable into summer. In addition, the frequently ice-associated genus Colwellia increased from February to abundances of $>20 \%$ in mid-June (Figs. 6b, 7a). Both SAR406 and Colwellia markedly correlated with ice cover (Spearman's rho $=0.7, p<0.0004$ ), suggesting that ice cover sustained these winter-type taxa into summer. As SAR406 might participate in sulfur cycling [95], loss of sea ice might diminish the recycling of inorganic substrates.

\section{Spring and summer}

Microbial succession in the WSC. Once daylight reached $\sim 20 \mathrm{~h}$ in mid-April, the microbial system returned to a phototrophic state. The winter-spring transition occurred within few weeks, comparable to warmer Pacific waters [96]. The average mixed layer depth of $>200 \mathrm{~m}$ until mid-June (Supplementary Table 3) likely facilitated strong phytoplankton growth. Eukaryotic composition changed ahead of bacterial communities, whose structure changed within four weeks after the primary photosynthetic peak (Supplementary Fig. 6). We observed three distinct bloom stages, featuring phototrophic pioneers (Phaeocystis and Chaetoceros) followed by araphid-pennate diatoms (Grammonema) and centric diatoms (Thalassiosira) (Fig. 7, Supplementary Fig. 8). A comparable threestage bloom has been observed a year before in nearby Kongsfjorden [97]. The replacement of eukaryotic heterotrophs by photoautotrophs (Fig. 3b, Supplementary Fig. 6) suggests considerable energy fluxes around the winter-spring transition, with possible effects on benthopelagic coupling [98-100]. The early detection of Aurantivirga and SAR92 (Supplementary Fig. 6) matched observations during the Antarctic spring bloom [17], indicating comparable temporal niches at both poles. The Grammonema abundance of $>50 \%$ in May coincided with peaking chlorophyll, potentially fueling intermittent peaks of Formosa, Polaribacter, and NS clades from family Flavobacteriaceae (Fig. 7a), comparable to diatom-flavobacteria relationships in temperate and Antarctic waters [54, 101].

Thalassiosira was specific for summer and the final bloom stage, when nitrate and phosphate declined and oxygen concentrations peaked (Fig. 7). The average mixed layer depth in summer was 23 m (Supplementary Table 3); hence, the RAS sampled just below the productive layer. The relative increase of mixotrophic flagellates (e.g., Gyrodinium and Woloszynskia) and concurrently decreasing chlorophyll indicates that trophic structure shifted towards heterotrophy. Increase of the roseobacter Amylibacter (formerly NAC11-7) to $15 \%$ sequence abundance emphasized the beginning transition to the autumn post-bloom where Rhodobacteraceae dominated (Fig. 4). We hypothesize concurrent generation of detritus particles, given the typical termination of diatom blooms by aggregation [68] and the association of Amylibacter with related particles [102]. Furthermore, the appearance of ectoparasitoid dinoflagellates such as Chytriodinium indicates beginning parasitism on diatoms and larger metazoans [103].

Absence of major phototrophic peaks in the EGC. Diatom abundances resembled those during winter (Supplementary Fig. 5b), with threefold lower chlorophyll concentrations than 

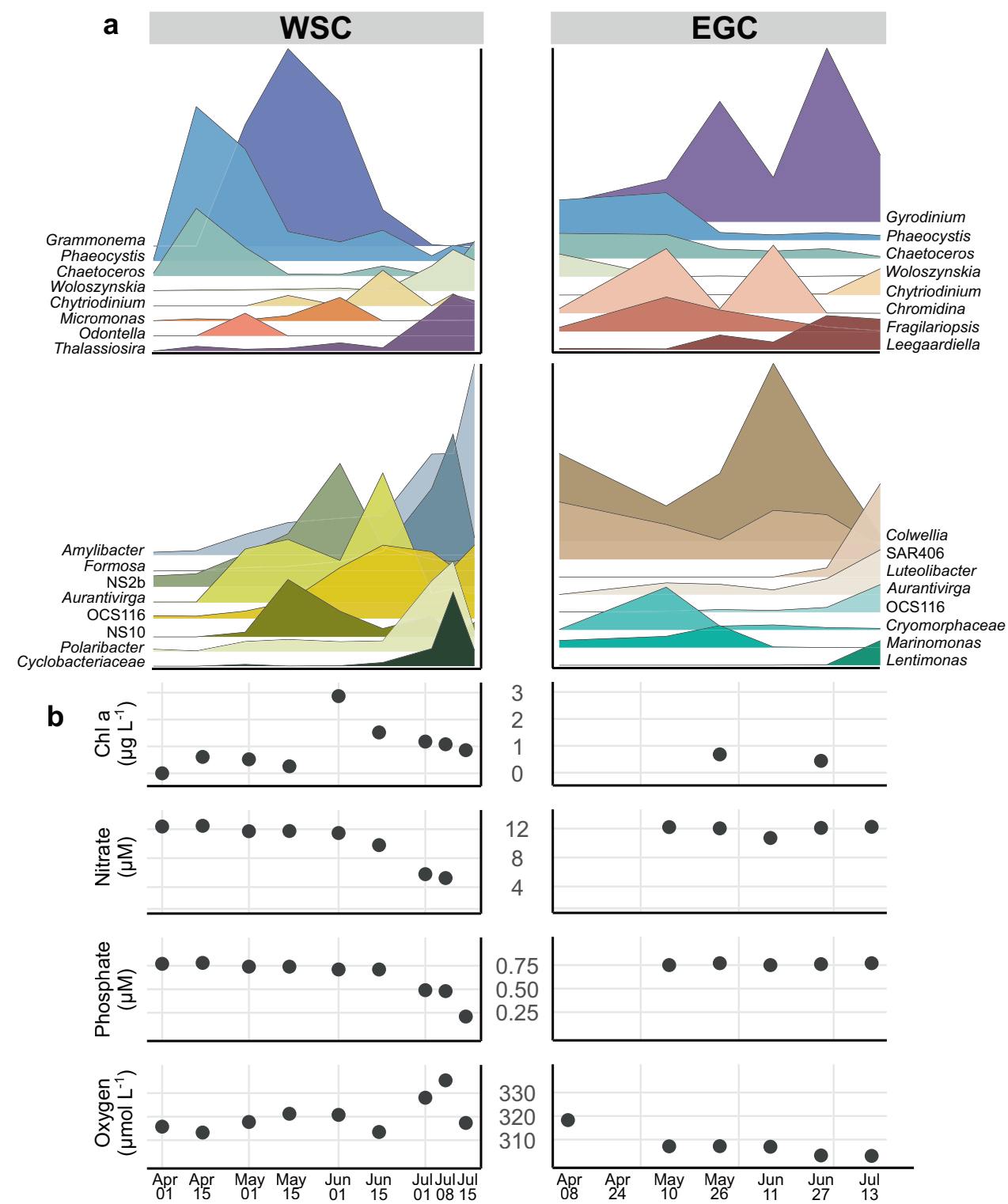

Fig. 7 Spring and summer dynamics. a Relative abundances of dominant eukaryotic and bacterial genera (see Supplementary Fig. 8 for detailed abundances). $\mathbf{b}$ Concentrations of chlorophyll, nitrate, phosphate and oxygen.

the WSC peak (Fig. 7b). Fragilariopsis and Chaetoceros together only constituted $<10 \%$ of eukaryotic sequences, although nutrients were not limiting (Fig. 7b, Supplementary Table 3). Furthermore, Phaeocystis only reached $9 \%$ and hence a quarter of WSC proportions. These observations corroborate the influence of sampling depth, i.e. that phytoplankton sequences merely mirror preceding surface dynamics and export flux. This constant input of detrital material presumably also explains why Syndiniales prevailed over summer (Fig. 4), together with major peaks of the mixotrophs Chromidina (Ciliophora) and Gyrodinium (Dinoflagellata) that constituted up to $35 \%$ of eukaryote sequences. Chromidina is normally considered an animal parasite, suggesting yet undescribed free-living niches in the marginal ice zone. The prevalence of mixotrophy was underlined by the earlier detection of Woloszynskia, and twofold lower flavobacterial abundances compared to the WSC (Figs. 2a, 4b). Moreover, the typical phytoplankton associates OCS116, Lentimonas and Luteolibacter $[104,105]$ were only detected from mid-summer, following EGCspecific Cryomorphaceae and Marinomonas peaks (Fig. 7a). The presence of ice cover over summer, likely resulting in continuous input of ice-derived substrates, indicates further differences in trophic structure. Ice substrates presumably fueled the major peak of Colwellia, which can efficiently grow on organic matter from sea ice [70].

\section{ECOLOGICAL CONCLUSIONS}

This first assessment of microbial seasonality in the Fram Strait by autonomous sampling identified marked seasonal contrasts, distinct transition events, as well as dynamic variability linked to polar vs. Atlantic conditions. The characterization of bloom stages, ephemeral abundance peaks, and polar night characteristics promotes the understanding of the drivers and timescales of microbial seasonality in ice-covered and ice-free Arctic waters. These insights yield a number of fundamental ecological conclusions, with implications for the present and future Arctic Ocean.

1. We identified major dynamics and drivers of microbiome structure in the Arctic Ocean: marked seasonal contrasts 
related to daylight, temperature and stratification in the euphotic zone of the ice-free WSC, compared to weaker seasonality related to ice cover, proportions of polar/Atlantic water masses and sampling depth in the EGC.

2. Dynamics in the WSC illustrate key principles of microbial seasonality in the ice-free, open Arctic Ocean: Phaeocystis as daylight pioneer followed by pennate diatoms and maximum chlorophyll concentrations when mixed layer depth was still >200 m (spring); declining nitrate and shift towards centric diatoms and mixotrophic flagellates upon increasing stratification (summer); minimum nutrients and highest temperatures when Coscinodiscophyceae diatoms and oligotrophic bacteria prevailed (autumn); and chemoautotrophic microbial recyclers and nutrient replenishment during vertical mixing (winter). Comparable observations have been made in a year-round study using Niskin-based sampling [11], illustrating that autonomous techniques provide results consistent with traditional approaches while considerably increasing temporal resolution. Moreover, our results remarkably overlap with a RAS-based study in the open Southern Ocean, which also reports Coscinodiscophyceae in autumn, Aurantivirga and SAR92 as first bacterial responders, and Amylibacter at the summer-autumn transition [17]. This suggests fundamental "bi-polar" patterns of microbial seasonality, only discernable by autonomous sampling.

3. The EGC exhibited combined effects of depth, ice cover and variable polar/Atlantic water masses, with a strong heterotrophic signature year-round. Seasonality and similarities to the WSC scaled with the extent of AW advection. At a maximum speed of $0.25 \mathrm{~m} \mathrm{~s}^{-1}$ [106], water from the WSC can reach the EGC within $\sim 2$ weeks, underlining how quickly hydrographic regimes can change and influence community composition. Polar-dominated conditions extended the duration and abundance of winter taxa such as SAR406 and Colwellia, with surface phytoplankton growth mainly detected during low ice in autumn. Periods of low ice coincided with higher abundances of Phaeocystis, Thalassiosira, OCS116 and Aurantivirga (Supplementary Fig. 7b). These dynamics are sentinels of how the future EGC might shift from an ice- to a light-driven habitat [107], presumably affecting the fate of phytoplankton blooms and the biological carbon pump [57, 108, 109]. Elevated photosynthesis and resulting higher amounts of organic substrates might accelerate the microbial loop [110], inducing the remineralization of ice-derived organic matter at the expense of chemoautotrophic metabolisms [70, 111].

4. Atlantification of the Arctic may enhance early blooms of Phaeocystis [15, 27] and alter biogeochemical fluxes, considering the associated production of TEP that serves as microbial substrate, microhabitat and downward vehicle of organic matter. In case stratification becomes stronger and more permanent with increasing temperatures, wintertime convection might diminish and deep-water "recycling taxa" disappear from the winter assemblage, with yet unknown ecological consequences.

In conclusion, the demonstrated seasonal microbiome dynamics and drivers contribute to the understanding of Arctic ecosystem functioning over polar day and night. This evidence is particularly relevant considering the anticipated impact of climate change on polar regions.

\section{REFERENCES}

1. Cavicchioli R, Ripple WJ, Timmis KN, Azam F, Bakken LR, Baylis M, et al. Scientists' warning to humanity: microorganisms and climate change. Nat Rev Microbiol. 2019:17:569-86.
2. Bunse C, Pinhassi J. Marine Bacterioplankton seasonal succession dynamics. Trends Microbiol. 2017;25:494-505.

3. Buttigieg PL, Fadeev E, Bienhold C, Hehemann L, Offre P, Boetius A. Marine microbes in 4D-using time series observation to assess the dynamics of the ocean microbiome and its links to ocean health. Curr Opin Microbiol. 2018;43:169-85.

4. Gilbert JA, Steele JA, Caporaso JG, Steinbrück L, Reeder J, Temperton B, et al. Defining seasonal marine microbial community dynamics. ISME J. 2012;6:298-308.

5. Cram JA, Chow C-ET, Sachdeva R, Needham DM, Parada AE, Steele JA, et al. Seasonal and interannual variability of the marine bacterioplankton community throughout the water column over ten years. ISME J. 2015;9:563-80.

6. Auladell A, Barberán A, Logares R, Garcés E, Gasol JM, Ferrera I. Seasonal niche differentiation among closely related marine bacteria. ISME J. 2021.

7. Alonso-Saez L, Sanchez O, Gasol JM, Balague V, Pedros-Alio C. Winter-tosummer changes in the composition and single-cell activity of near-surface Arctic prokaryotes. Environ Microbiol. 2008;10:2444-54.

8. Rokkan Iversen K, Seuthe L. Seasonal microbial processes in a high-latitude fjord (Kongsfjorden, Svalbard): I. Heterotrophic bacteria, picoplankton and nanoflagellates. Polar Biol. 2011;34:731-49.

9. Grzymski JJ, Riesenfeld CS, Williams TJ, Dussaq AM, Ducklow H, Erickson M, et al. A metagenomic assessment of winter and summer bacterioplankton from Antarctica Peninsula coastal surface waters. ISME J. 2012;6:1901-15.

10. Pedrós-Alió $C$, Potvin $M$, Lovejoy $C$. Diversity of planktonic microorganisms in the Arctic Ocean. Prog Oceanogr. 2015;139:233-43.

11. Wilson B, Müller O, Nordmann E-L, Seuthe L, Bratbak G, Øvreås L. Changes in marine prokaryote composition with season and depth over an Arctic polar year. Front Mar Sci. 2017;4:95.

12. Sandaa R-A, E Storesund J, Olesin E, Lund Paulsen M, Larsen A, Bratbak G, et al. Seasonality drives microbial community structure, shaping both eukaryotic and prokaryotic host-viral relationships in an Arctic marine ecosystem. Viruses. 2018;10:715.

13. Williams TJ, Long E, Evans F, Demaere $M Z$, Lauro FM, Raftery MJ, et al. A metaproteomic assessment of winter and summer bacterioplankton from Antarctic Peninsula coastal surface waters. ISME J. 2012;6:1883-900.

14. Freyria NJ, Joli N, Lovejoy C. A decadal perspective on north water microbial eukaryotes as Arctic Ocean sentinels. Sci Rep. 2021;11:8413.

15. Assmy $P$, Fernández-Méndez $M$, Duarte $P$, Meyer $A$, Randelhoff $A$, Mundy $C J$, et al. Leads in Arctic pack ice enable early phytoplankton blooms below snowcovered sea ice. Sci Rep. 2017;7:40850.

16. Hegseth EN, Assmy P, Wiktor JM, Wiktor J, Kristiansen S, Leu E, et al. Phytoplankton seasonal dynamics in Kongsfjorden, Svalbard and the adjacent shelf. In: Hop H, Wiencke C (eds). The ecosystem of Kongsfjorden, Svalbard. 2019. Springer International Publishing, Cham, pp 173-227.

17. Liu Y, Blain S, Crispi O, Rembauville M, Obernosterer I. Seasonal dynamics of prokaryotes and their associations with diatoms in the Southern Ocean as revealed by an autonomous sampler. Environ Microbiol. 2020;22:3968-84.

18. Randelhoff A, Lacour L, Marec C, Leymarie E, Lagunas J, Xing X, et al. Arctic midwinter phytoplankton growth revealed by autonomous profilers. Sci Adv. 2020;6:eabc2678.

19. Randelhoff A, Reigstad M, Chierici M, Sundfjord A, Ivanov V, Cape M, et al. Seasonality of the physical and biogeochemical hydrography in the inflow to the Arctic Ocean through Fram Strait. Front Mar Sci. 2018;5:224.

20. Berge J, Renaud PE, Darnis G, Cottier F, Last K, Gabrielsen TM, et al. In the dark: a review of ecosystem processes during the Arctic polar night. Prog Oceanogr. 2015;139:258-71.

21. Müller $O$, Wilson $B$, Paulsen ML, Rumińska A, Armo HR, Bratbak G, et al. Spatiotemporal dynamics of ammonia-oxidizing thaumarchaeota in distinct arctic water masses. Front Microbiol. 2018;9:24

22. Johnsen G, Leu E, Gradinger R. Marine micro- and macroalgae in the polar night. In: Berge J, Johnsen G, Cohen JH (eds). Polar night marine ecology: life and light in the dead of night. 2020. Springer International Publishing, Cham, pp 67-112.

23. Vader A, Marquardt M, Meshram A, Gabrielsen T. Key Arctic phototrophs are widespread in the polar night. Polar Biol. 2014;38:13-21.

24. Leu E, Mundy CJ, Assmy P, Campbell K, Gabrielsen TM, Gosselin M, et al. Arctic spring awakening - steering principles behind the phenology of vernal ice algal blooms. Prog Oceanogr. 2015;139:151-70.

25. Soltwedel T, Bauerfeind E, Bergmann M, Bracher A, Budaeva N, Busch K, et al. Natural variability or anthropogenically-induced variation? Insights from 15 years of multidisciplinary observations at the arctic marine LTER site HAUSGARTEN. Ecol Indic. 2016;65:89-102.

26. Nöthig E-M, Ramondenc S, Haas A, Hehemann L, Walter A, Bracher A, et al. Summertime chlorophyll a and particulate organic carbon standing stocks in surface waters of the Fram Strait and the Arctic Ocean (1991-2015). Front Mar Sci. 2020;7:350. 
27. Nöthig E-M, Bracher A, Engel A, Metfies K, Niehoff B, Peeken I, et al. Summertime plankton ecology in Fram Strait-a compilation of long- and short-term observations. Polar Res. 2015;34:23349.

28. Engel A, Bracher A, Dinter T, Endres S, Grosse J, Metfies K, et al. Inter-annual variability of organic carbon concentration in the Eastern Fram Strait during summer (2009-17). Front Mar Sci. 2019;6:187.

29. Fadeev E, Salter I, Schourup-Kristensen V, Nöthig E-M, Metfies K, Engel A, et al. Microbial communities in the east and west Fram Strait during sea ice melting season. Front Mar Sci. 2018;5:429.

30. von Jackowski A, Grosse J, Nöthig E-M, Engel A. Dynamics of organic matter and bacterial activity in the Fram Strait during summer and autumn. Philos Trans R Soc Math Phys Eng Sci. 2020;378:20190366.

31. Metfies K, Bauerfeind E, Wolf $C$, Sprong $P$, Frickenhaus $S$, Kaleschke $L$, et al. Protist communities in moored long-term sediment traps (Fram Strait, Arctic)-preservation with mercury chloride allows for PCR-based molecular genetic analyses. Front Mar Sci. 2017;4:301.

32. Cardozo-Mino MG, Fadeev E, Salman-Carvalho V, Boetius A. Spatial distribution of Arctic bacterioplankton abundance is linked to distinct water masses and summertime phytoplankton bloom dynamics (Fram Strait, $79^{\circ} \mathrm{N}$ ). Front Microbiol. 2021;12:658803.

33. Richter ME, von Appen W-J, Wekerle C. Does the East Greenland Current exist in the northern Fram Strait? Ocean Sci. 2018;14:1147-65.

34. Tuerena RE, Hopkins J, Buchanan PJ, Ganeshram RS, Norman L, von Appen W-J, et al. An Arctic strait of two halves: the changing dynamics of nutrient uptake and limitation across the Fram Strait. Glob Biogeochem Cycles. 2021;35: e2021GB006961.

35. Polyakov IV, Pnyushkov AV, Alkire MB, Ashik IM, Baumann TM, Carmack EC, et al. Greater role for Atlantic inflows on sea-ice loss in the Eurasian Basin of the Arctic Ocean. Science. 2017;356:285-91.

36. Lannuzel D, Tedesco L, van Leeuwe M, Campbell K, Flores H, Delille B, et al. The future of Arctic sea-ice biogeochemistry and ice-associated ecosystems. Nat Clim Change. 2020;10:983-92.

37. Carter-Gates M, Balestreri C, Thorpe SE, Cottier F, Baylay A, Bibby TS, et al. Implications of increasing Atlantic influence for Arctic microbial community structure. Sci Rep. 2020;10:19262.

38. Parada AE, Needham DM, Fuhrman JA. Every base matters: assessing small subunit rRNA primers for marine microbiomes with mock communities, time series and global field samples. Environ Microbiol. 2016;18:1403-14.

39. Martin M. Cutadapt removes adapter sequences from high-throughput sequencing reads. EMBnet.journal 2011;17:10-2.

40. Callahan BJ, McMurdie PJ, Rosen MJ, Han AW, Johnson AJA, Holmes SP. DADA2: High-resolution sample inference from Illumina amplicon data. Nat Methods. 2016;13:581-3.

41. Quast C, Pruesse E, Yilmaz P, Gerken J, Schweer T, Yarza P, et al. The SILVA ribosomal RNA gene database project: improved data processing and webbased tools. Nucleic Acids Res. 2013;41:D590-596.

42. Guillou L, Bachar D, Audic S, Bass D, Berney C, Bittner L, et al. The Protist Ribosomal Reference database (PR2): a catalog of unicellular eukaryote Small Sub-Unit rRNA sequences with curated taxonomy. Nucleic Acids Res. 2013;41: D597-D604.

43. Hsieh TC, Ma KH, Chao A. iNEXT: an R package for rarefaction and extrapolation of species diversity (Hill numbers). Methods Ecol Evol. 2016;7:1451-6.

44. Wickham H, Averick M, Bryan J, Chang W, McGowan LD, François R, et al. Welcome to the Tidyverse. J Open Source Softw. 2019;4:1686.

45. McMurdie PJ, Holmes S. phyloseq: an R package for reproducible interactive analysis and graphics of microbiome census data. PLOS ONE. 2013;8:e61217.

46. Andersen KSS, Kirkegaard RH, Karst SM, Albertsen M. ampvis2: an R package to analyse and visualise 16S rRNA amplicon data. bioRxiv. 2018.

47. Lawlor J. PNWColors: A Pacific Northwest inspired R color palette package. 2020 https://github.com/jakelawlor/PNWColors.

48. von Appen W-J, Schauer U, Hattermann T, Beszczynska-Möller A. Seasonal cycle of mesoscale instability of the west Spitsbergen Current. J Phys Oceanogr. 2016;46:1231-54.

49. Wekerle C, Wang Q, von Appen W-J, Danilov S, Schourup-Kristensen V, Jung T. Eddy-resolving simulation of the Atlantic water circulation in the Fram Strait with focus on the seasonal cycle. J Geophys Res Oceans. 2017;122:8385-405.

50. Giner CR, Balagué V, Krabberød AK, Ferrera I, Reñé A, Garcés E, et al. Quantifying long-term recurrence in planktonic microbial eukaryotes. Mol Ecol. 2019;28:923-35.

51. Royo-Llonch M, Sánchez $P$, Ruiz-González C, Salazar G, Pedrós-Alió C, Sebastián $M$, et al. Compendium of 530 metagenome-assembled bacterial and archaeal genomes from the polar Arctic Ocean. Nat. Microbiol. 2021;6:1561-74.

52. Priest T, Orellana LH, Huettel B, Fuchs BM, Amann R. Microbial metagenomeassembled genomes of the Fram Strait from short and long read sequencing platforms. PeerJ. 2021;9:e11721.
53. Sunagawa S, Coelho LP, Chaffron S, Kultima JR, Labadie K, Salazar G, et al. Structure and function of the global ocean microbiome. Science. 2015;348:1261359.

54. Teeling $H$, Fuchs BM, Becher D, Klockow C, Gardebrecht A, Bennke CM, et al. Substrate-controlled succession of marine bacterioplankton populations induced by a phytoplankton bloom. Science. 2012;336:608-11.

55. Monier A, Comte J, Babin M, Forest A, Matsuoka A, Lovejoy C. Oceanographic structure drives the assembly processes of microbial eukaryotic communities. ISME J. 2015;9:990-1002.

56. Leeuwe M, van, Tedesco L, Arrigo KR, Assmy P, Campbell K, Meiners KM, et al. Microalgal community structure and primary production in Arctic and Antarctic sea ice: a synthesis. Elem Sci Anth. 2018;6:4.

57. Fadeev E, Rogge A, Ramondenc S, Nöthig E-M, Wekerle C, Bienhold C, et al. Sea ice presence is linked to higher carbon export and vertical microbial connectivity in the Eurasian Arctic Ocean. Commun Biol. 2021;4:1-13.

58. Wasmund N, Göbel J, von Bodungen B. 100-years-changes in the phytoplankton community of Kiel Bight (Baltic Sea). J Mar Syst. 2008;73:300-22.

59. Stoecker DK, Lavrentyev PJ. Mixotrophic plankton in the polar seas: a pan-Arctic review. Front Mar Sci. 2018;5:292.

60. Lampe V, Nöthig E-M, Schartau M. Spatio-temporal variations in community size structure of Arctic protist plankton in the Fram Strait. Front Mar Sci. 2021;7:579880.

61. Brichta M, Nöthig E-M. The role of life cycle stages of diatoms in decoupling carbon and silica cycles in polar regions. In: Proceedings of SCAR Open Science Conference Bremen, Germany. 2004.

62. Not F, Siano R, Kooistra WHCF, Simon N, Vaulot D, Probert I. Diversity and ecology of eukaryotic marine phytoplankton. In: Piganeau G (ed). Advances in botanical research. 2012. Academic Press, pp 1-53.

63. Raghukumar S. Ecology of the marine protists, the Labyrinthulomycetes (Thraustochytrids and Labyrinthulids). Eur J Protistol. 2002;38:127-45.

64. Scholz B, Guillou L, Marano AV, Neuhauser S, Sullivan BK, Karsten U, et al. Zoosporic parasites infecting marine diatoms-a black box that needs to be opened. Fungal Ecol. 2016;19:59-76.

65. Choi DH, Park K-T, An SM, Lee K, Cho J-C, Lee J-H, et al. Pyrosequencing revealed SAR1 16 clade as dominant dddP-containing bacteria in oligotrophic NW Pacific Ocean. PLOS One. 2015;10:e0116271.

66. Wemheuer B, Wemheuer F, Hollensteiner J, Meyer F-D, Voget S, Daniel R. The green impact: bacterioplankton response toward a phytoplankton spring bloom in the southern North Sea assessed by comparative metagenomic and metatranscriptomic approaches. Front Microbiol. 2015;6:805.

67. Delpech L-M, Vonnahme TR, McGovern M, Gradinger R, Præbel K, Poste A. Terrestrial inputs shape coastal bacterial and archaeal communities in a high Arctic Fjord (Isfjorden, Svalbard). Front Microbiol. 2021;12:614634.

68. Alldredge AL, Gotschalk CC. Direct observations of the mass flocculation of diatom blooms: characteristics, settling velocities and formation of diatom aggregates. Deep Sea Res Part A. Oceanogr Res Pap. 1989;36:159-71.

69. Lundholm N, Hansen PJ, Kotaki Y. Effect of $\mathrm{pH}$ on growth and domoic acid production by potentially toxic diatoms of the genera Pseudo-nitzschia and Nitzschia. Mar Ecol Prog Ser. 2004;273:1-15.

70. Underwood GJC, Michel C, Meisterhans G, Niemi A, Belzile C, Witt M, et al. Organic matter from Arctic sea-ice loss alters bacterial community structure and function. Nat Clim Change. 2019;9:170-6.

71. Graham E, Tully BJ. Marine Dadabacteria exhibit genome streamlining and phototrophy-driven niche partitioning. ISME J. 2021;15:1248-56.

72. Clarke U, Bestley S, Bissett A, Deagle BE. A globally distributed Syndiniales parasite dominates the Southern Ocean micro-eukaryote community near the sea-ice edge. ISME J. 2019;13:734-7.

73. Randelhoff A, Sundfjord A, Reigstad M. Seasonal variability and fluxes of nitrate in the surface waters over the Arctic shelf slope. Geophys Res Lett. 2015;42:3442-9.

74. García FC, Alonso-Sáez L, Morán XAG, López-Urrutia Á. Seasonality in molecular and cytometric diversity of marine bacterioplankton: the re-shuffling of bacterial taxa by vertical mixing. Environ Microbiol. 2015;17:4133-42.

75. Jousset A, Bienhold C, Chatzinotas A, Gallien L, Gobet A, Kurm V, et al. Where less may be more: how the rare biosphere pulls ecosystems strings. ISME J. 2017; 11:853-62.

76. Giner CR, Pernice MC, Balagué V, Duarte CM, Gasol JM, Logares R, et al. Marked changes in diversity and relative activity of picoeukaryotes with depth in the world ocean. ISME J. 2020;14:437-49.

77. Lehtovirta-Morley LE. Ammonia oxidation: ecology, physiology, biochemistry and why they must all come together. FEMS Microbiol Lett. 2018;365:fny058.

78. Williams TJ, Lefevre CT, Zhao W, Beveridge TJ, Bazylinski DA. Magnetospira thiophila gen. nov., sp. nov., a marine magnetotactic bacterium that represents a novel lineage within the Rhodospirillaceae (Alphaproteobacteria). Int J Syst Evol Microbiol. 2012;62:2443-50.

79. von Friesen LW, Riemann L. Nitrogen fixation in a changing Arctic Ocean: an overlooked source of nitrogen? Front Microbiol. 2020;11:596426. 
80. Alonso-Saez L, Waller AS, Mende DR, Bakker K, Farnelid H, Yager PL, et al. Role for urea in nitrification by polar marine archaea. Proc Natl Acad Sci USA. 2012;109:17989-94.

81. Martínez-Pérez C, Greening C, Zhao Z, Lappan RJ, Bay SK, De Corte D, et al. Lifting the lid: nitrifying archaea sustain diverse microbial communities below the Ross Ice Shelf. Cell Rev. 2020; SSRN: https://ssrn.com/abstract $=3677479$ or https://doi.org/10.2139/ssrn.3677479.

82. Mohamed NM, Saito K, Tal Y, Hill RT. Diversity of aerobic and anaerobic ammonia-oxidizing bacteria in marine sponges. ISME J. 2010;4:38-48.

83. Mussmann M, Pjevac P, Kruger K, Dyksma S. Genomic repertoire of the Woeseiaceae/JTB255, cosmopolitan and abundant core members of microbial communities in marine sediments. ISME J. 2017;11:1276-81.

84. Burow LC, Kong Y, Nielsen JL, Blackall LL, Nielsen PH. Abundance and ecophysiology of Defluviicoccus spp., glycogen-accumulating organisms in full-scale wastewater treatment processes. Microbiology. 2007;153:178-85.

85. Lucas J, Koester I, Wichels A, Niggemann J, Dittmar T, Callies U, et al. Short-term dynamics of North Sea Bacterioplankton-dissolved organic matter coherence on molecular level. Front Microbiol. 2016;7:321.

86. Stecher A, Neuhaus S, Lange B, Frickenhaus S, Beszteri B, Kroth PG, et al. rRNA and rDNA based assessment of sea ice protist biodiversity from the central Arctic Ocean. Eur J Phycol. 2016;51:31-46.

87. Lalande C, Nöthig E-M, Somavilla R, Bauerfeind E, Shevchenko V, Okolodkov Y. Variability in under-ice export fluxes of biogenic matter in the Arctic Ocean. Glob Biogeochem Cycles. 2014;28:571-83.

88. Hoffmann K, Hassenrück C, Salman-Carvalho V, Holtappels M, Bienhold C. Response of bacterial communities to different detritus compositions in Arctic deep-sea sediments. Front Microbiol. 2017;8:266.

89. Kappelmann L, Krüger K, Hehemann J-H, Harder J, Markert S, Unfried F, et al. Polysaccharide utilization loci of North Sea Flavobacteriia as basis for using SusC/D-protein expression for predicting major phytoplankton glycans. ISME J. 2019;13:76-91.

90. Izaguirre I, Unrein F, Schiaffino MR, Lara E, Singer D, Balagué V, et al. Phylogenetic diversity and dominant ecological traits of freshwater Antarctic Chrysophyceae. Polar Biol. 2021;44:941-57.

91. Humphry DR, George A, Black GW, Cummings SP. Flavobacterium frigidarium sp. nov., an aerobic, psychrophilic, xylanolytic and laminarinolytic bacterium from Antarctica. Int J Syst Evol Microbiol. 2001;51:1235-43.

92. Rapp JZ, Fernández-Méndez M, Bienhold C, Boetius A. Effects of ice-algal aggregate export on the connectivity of bacterial communities in the central Arctic Ocean. Front Microbiol. 2018;9:1035.

93. Ardyna M, Mundy CJ, Mayot N, Matthes LC, Oziel L, Horvat C, et al. Under-ice phytoplankton blooms: shedding light on the "invisible" part of Arctic primary production. Front Mar Sci. 2020;7:608032.

94. Alonso-Sáez L, Zeder M, Harding T, Pernthaler J, Lovejoy C, Bertilsson S, et al. Winter bloom of a rare betaproteobacterium in the Arctic Ocean. Front Microbiol. 2014;5:425.

95. Hawley AK, Nobu MK, Wright JJ, Durno WE, Morgan-Lang C, Sage B, et al. Diverse Marinimicrobia bacteria may mediate coupled biogeochemical cycles along eco-thermodynamic gradients. Nat Commun. 2017;8:1507.

96. Berdjeb L, Parada A, Needham DM, Fuhrman JA. Short-term dynamics and interactions of marine protist communities during the spring-summer transition. ISME J. 2018;12:1907-17.

97. Singh A, Divya DT, Tripathy SC, Naik RK. Interplay of regional oceanography and biogeochemistry on phytoplankton bloom development in an Arctic fjord. Estuar Coast Shelf Sci. 2020;243:106916.

98. Engel A, Piontek J, Metfies K, Endres S, Sprong P, Peeken I, et al. Inter-annual variability of transparent exopolymer particles in the Arctic Ocean reveals high sensitivity to ecosystem changes. Sci Rep. 2017;7:4129.

99. Nejstgaard JC, Tang KW, Steinke M, Dutz J, Koski M, Antajan E, et al. Zooplankton grazing on Phaeocystis: a quantitative review and future challenges. Biogeochemistry. 2007;83:147-72.

100. Lampitt RS, Salter I, Johns D. Radiolaria: major exporters of organic carbon to the deep ocean. Glob Biogeochem Cycles. 2009;23:GB1010.

101. Luria CM, Amaral-Zettler LA, Ducklow HW, Rich JJ. Seasonal succession of freeliving bacterial communities in coastal waters of the western Antarctic Peninsula. Front Microbiol. 2016;7:1731.

102. Taylor JD, Cunliffe M. Coastal bacterioplankton community response to diatomderived polysaccharide microgels. Environ Microbiol Rep. 2017;9:151-7.

103. Gómez-Gutiérrez J, Kawaguchi S, Nicol S. Epibiotic suctorians and enigmatic ecto- and endoparasitoid dinoflagellates of euphausiid eggs (Euphausiacea) off Oregon, USA. J Plankton Res. 2009;31:777-85.

104. Cardman Z, Arnosti C, Durbin A, Ziervogel K, Cox C, Steen AD, et al. Verrucomicrobia: candidates for polysaccharide-degrading bacterioplankton in an Arctic fjord of Svalbard. Appl Environ Microbiol. 2014;80:3749-56.
105. Landa M, Blain S, Harmand J, Monchy S, Rapaport A, Obernosterer I. Major changes in the composition of a Southern Ocean bacterial community in response to diatom-derived dissolved organic matter. FEMS Microbiol Ecol. 2018;94:fiy034.

106. Fahrbach E, Meincke J, Østerhus S, Rohardt G, Schauer U, Tverberg V, et al. Direct measurements of volume transports through Fram Strait. Polar Res. 2001;20:217-24.

107. Comeau AM, Li WK, Tremblay JE, Carmack EC, Lovejoy C. Arctic Ocean microbial community structure before and after the 2007 record sea ice minimum. PLOS ONE. 2011;6:e27492.

108. Lalande C, Bauerfeind E, Nöthig E-M, Beszczynska-Möller A. Impact of a warm anomaly on export fluxes of biogenic matter in the eastern Fram Strait. Prog Oceanogr. 2013;109:70-7.

109. Dybwad C, Assmy P, Olsen LM, Peeken I, Nikolopoulos A, Krumpen T, et al. Carbon export in the seasonal sea ice zone north of Svalbard from winter to late summer. Front Mar Sci. 2021;7:525800.

110. Glud RN, Rysgaard S, Turner G, McGinnis DF, Leakey RJG. Biological- and physical-induced oxygen dynamics in melting sea ice of the Fram Strait. Limnol Oceanogr. 2014;59:1097-111.

111. Shiozaki T, ljichi M, Fujiwara A, Makabe A, Nishino S, Yoshikawa C, et al. Factors regulating nitrification in the Arctic Ocean: potential impact of sea ice reduction and ocean acidification. Glob Biogeochem Cycles. 2019;33:1085-99.

\section{ACKNOWLEDGEMENTS}

We thank Jana Bäger, Theresa Hargesheimer, Rafael Stiens, and Lili Hufnagel for RAS operation; Daniel Scholz for RAS and sensor operations and programming; Normen Lochthofen, Janine Ludszuweit, Lennard Frommhold, and Jonas Hagemann for mooring operation; Jakob Barz and Swantje Rogge for DNA extraction and library preparation; Halina Tegetmeyer for quality control and sequencing of $16 \mathrm{~S}$ rRNA amplicons; and Laura Wischnewski for nutrient analysis. Christiane Hassenrück, Stefan Neuhaus, Pier L. Buttigieg, Magda Cardozo-Mino and Andrew B. Collier contributed bioinformatic assistance. We thank Eva-Maria Nöthig for constructive discussions and the entire FRAM team for excellent collaboration. The captain, crew and scientists of RV Polarstern cruises PS99 and PS107 are gratefully acknowledged. Ship time was provided under grants AWI_PS99_00 and AWI_PS107_05. This project has received funding from the European Research Council (ERC) under the European Union's Seventh Framework Program (FP7/2007-2013) research project ABYSS (Grant Agreement no. 294757) to AB. Additional funding came from the Helmholtz Association, specifically for the FRAM infrastructure and from the Max Planck Society.

\section{AUTHOR CONTRIBUTIONS}

MW performed sequence analysis, statistical evaluation, and wrote the paper. CB contributed to sampling design, data interpretation and data management. KM provided eukaryotic sequence data and contributed to data interpretation. STV performed nutrient quantification and quality control. WJvA contributed qualitycontrolled oceanographic data, and coordinated the mooring operations. IS and $A B$ designed the autonomous sampling and mooring strategy. All authors contributed to the final manuscript.

\section{FUNDING}

Open Access funding enabled and organized by Projekt DEAL.

\section{COMPETING INTERESTS}

The authors declare no competing interests.

\section{ADDITIONAL INFORMATION}

Supplementary information The online version contains supplementary material available at https://doi.org/10.1038/s43705-021-00074-4.

Correspondence and requests for materials should be addressed to Matthias Wietz or Antje Boetius.

Reprints and permission information is available at http://www.nature.com/ reprints

Publisher's note Springer Nature remains neutral with regard to jurisdictional claims in published maps and institutional affiliations. 
(c) (i) Open Access This article is licensed under a Creative Commons Attribution 4.0 International License, which permits use, sharing, adaptation, distribution and reproduction in any medium or format, as long as you give appropriate credit to the original author(s) and the source, provide a link to the Creative Commons license, and indicate if changes were made. The images or other third party material in this article are included in the article's Creative Commons license, unless indicated otherwise in a credit line to the material. If material is not included in the article's Creative Commons license and your intended use is not permitted by statutory regulation or exceeds the permitted use, you will need to obtain permission directly from the copyright holder. To view a copy of this license, visit http://creativecommons. org/licenses/by/4.0/.

(c) The Author(s) 2021 